\title{
Experimental and theoretical investigation of drying kinetics of banana slices
}

\section{Muz dilimlerinin kurutma kinetiğinin deneysel ve teorik incelenmesi}

\author{
Burak TÜRKAN ${ }^{1}$ (D) , Akın Burak ETEMOĞLU² \\ 1,2Mechanical Engineering Department, Faculty of Engineering, Uludag University, Bursa, Turkey. \\ burakt@uludag.edu.tr, aetem@uludag.edu.tr
}

Received/Geliş Tarihi: 05.12.2018

Revision/Düzeltme Tarihi: 20.07.2019

doi: $10.5505 /$ pajes.2019.84484

Accepted/Kabul Tarihi: 31.07.2019

Research Article/Araștırma Makalesi

\begin{abstract}
Modeling of the hot air dehydration period is very important to increase food property and reduce energy consumption. The objective of the study is to examine the drying behaviour of banana slices by using convective hot air drying method. Drying kinetics of the banana slices was investigated experimentally for different air temperatures $\left(40,50\right.$, and $\left.60^{\circ} \mathrm{C}\right)$. The drying models were fitted to the experimental data. The model which gives the nearest results to the experimental information was predicted as the Midilli model $\left(R^{2}=0.99\right)$. It was determined that the $L$ (brightness) colour parameter value declined as the moisture content of the food decreased. Effective diffusion coefficients $\left(2.02 \times 10^{-10}, 5.05 \times 10^{-10}\right.$, and $\left.8.08 \times 10^{-10} \mathrm{~m}^{2} \mathrm{~s}^{-1}\right)$, activation energy $\left(61.1 \mathrm{~kJ}(\mathrm{~mol})^{-1}\right)$ and shrinkage coefficients (23\%,32\% and $40 \%)$ were calculated and it was seen to be compatible with the data given in the literature on food drying. The temperature and moisture content obtained from the experimental study were compared with numerical analysis and found to be compatible.
\end{abstract}

Keywords: Convective drying; Shrinkage, Banana.
Öz

Sicak hava ile kurutma modellenmesi, gida kalitesini arttırmak ve enerji tüketimini azaltmak için çok önemlidir. Çalışmanın amacı, sıcak hava kurutma yöntemi ile muz dilimlerinin kuruma davranıșlarını incelemektir. Muz dilimlerinin kurutma kinetiği, farklı hava sıcaklıklar $\left(40,50\right.$ ve $\left.60^{\circ} \mathrm{C}\right)$ için deneysel olarak incelenmistir. Kurutma modelleri deneysel verilere uygulanmıștır. Deneysel verilere en yakın sonuçları veren model Midilli modeli $\left(R^{2}=0.99\right)$ olarak tahmin edilmiștir. Ürünün nem içeriği azaldıkça $L$ (parlaklık) renk değerinin azaldığı belirlenmiştir. Efektif difüzyon katsayıları $\left(2.02 \times 10^{-10}, 5.05 \times 10^{-10}\right.$ ve $\left.8.08 \times 10^{-10} \mathrm{~m}^{2} \mathrm{~s}^{-1}\right)$, aktivasyon enerjisi $\left(61.1 \mathrm{~kJ}(\mathrm{~mol})^{-1}\right)$ ve büzülme katsayıları (\%23, \%32 ve \%40) hesaplanmış ve sonuçların gıda kurutulması üzerinde literatürde verilen bilgiler ile uyumlu olduğu görülmüştür. Deneysel çalıșmadan elde edilen sıcaklık ve nem içeriği değerleri nümerik analiz sonuçları ile karşılaştırılmıș ve uyumlu olduğu bulunmustur.

Anahtar kelimeler: Konvektif kurutma, Büzülme, Muz

\section{Introduction}

Bananas among food products are widely consumed in many countries. Banana has is very nutritious due to containing protein, fiber, fat acid, minerals and vitamin $\mathrm{E}$ such as magnesium, copper, and iron [1]. Fruits and vegetables containing water cause spoilage. Therefore, the drying process is used in the conservation of agricultural products. This process provides long-term protection without loosing the vitamin value of the product [2]

Sun drying is one of the habitual approaches utilized for dehydration of farming foods. However, convective dehydration is the most common industrial structure due to the homogeneous and fast dehydration procedure [3].

The air drying process usually consists of a term of constant rate, followed by a period of falling rate. In the constant rate term, the surface is covered with water. As the water evaporates, the mass transfer to air from the surface occurs. In the falling rate duration, humidity transfer is directed by interior mass transfer structures such as liquid, vapor diffusion, and capillary flow. Two falling rate periods occur in hygroscopic materials during drying. The wet surface area decreases as the moisture content of food vaporizes in the initial falling rate period. After the surface dries, the second decreasing ratio term begins, and evaporation occurs inside of the product [4].

The drying of farm products containing high moisture usually creates a remarkable deformation effect. The shrinkage effect occurring in food products has a powerful impact on the drying ratio and on the structure of the dried food and is observable [5].

Fick's law of diffusion is used to describe the drying kinetics. The thin layer drying models obtained by using this law are frequently encountered in the literature. The Lewis model [6]; Henderson and Pabis model [7]; Two Term model [8]; Wang and Singh model [9]; Midilli model [10] can be given as examples. These models are classified as theoretical, semi-theoretical, and experimental The drying process and kinetics of agricultural products have been investigated by many researchers in the literature [11]-[19]. The drying kinetics is important for determining the moisture content of the product and determining the drying time. At the same time, the quality of the dried products should be checked in order not to deteriorate. For this purpose, it is important to examine the quality parameters (colour, rehydration ratio, activation energy etc.) while determining the drying behavior of the products.

In the literature, it is possible to find many studies conducted separately on drying characteristic kinetic, colour analysis,

${ }^{*}$ Corresponding author/Yazışılan Yazar 
drying models, activation energy, effective diffusion coefficient, and shrinkage effect. The studies conducted on the banana drying in the literature can be summarized as follows: Karim and Hawlader [11] improved a mathematical model working out the heat and mass transfer equalities during the drying of bananas with the forced convection in their study. With the data they obtained from the experiment, they confirmed the model they developed and conducted a parametric study for different drying conditions. They also calculated the effective diffusion coefficients of banana. Samadi et al. [12] examined the drying of banana of different thicknesses. Using mathematical models, they found the Midilli model to be the most suitable model for their study. Thuwanapicyanana et al. [13] explored the affect of temperature on banana drying. They also examined the drying rate, colour analysis, deformation, and product microstructure. Baini and Langrish [14] examined the effect of temperature and moisture content on the product diffusivity for the banana drying process. Nguyen and Price [15] examined the effects of test parameters such as temperature, moisture, and thickness on the drying of bananas. Fernando et al. [16] studied the impression of the thicknesses of different banana slices on the effective diffusion coefficient in the convective dryer. Silva et al. [17] used three different diffusion models to determine the drying. The researchers solved the diffusion equations analytically using boundary conditions and compared the results with the experimental study. Joardder et al. [18] used the IMCD (intermittent microwave convective) method to improve energy efficiency and drying quality. Multiphase porous media approach method has been developed describing heat and mass transfer mechanism. Finally, they discussed the change of evaporation and vapor pressure. Saha et al. [19] developed two diffusion models by adding the shrinkage effect. The authors recommended that the shrinkage effect should be added to the thin-layer dehydrate models for better drying results. And, they also examined the quality of the food during dehydration. In this study, the effect of drying air temperature in the drying process was investigated. Therefore, while choosing the air temperaure $\left(40,50\right.$ and $\left.60{ }^{\circ} \mathrm{C}\right)$ and air velocity $\left(0.5 \mathrm{~ms}^{-1}\right)$ it was preferred to be over the values used in the some studies in the literature [11],[20].

In the literature, colour measurement, effective diffusion coefficient calculation, application of drying models, activation energy, shrinkage calculation and numerical verification studies are discussed. In this study, it is aimed to contribute to academic and industrial users by calculating these values besides drying kinetics of the product experimentally. Moisture content and drying ratio of food were obtained during convective drying process for different air temperatures $\left(40,50\right.$ and $\left.60^{\circ} \mathrm{C}\right)$. Our study provides an approach to estimate colour due to moisture content during drying. The numerical model was proposed to estimate simultaneous moisture and temperature distribution inside the food product. Five drying models were also used to find the best fit to experimental data. Finally, it was determined effective diffusion coefficients, shrinkage coefficient and activation energy at the end of the six hour drying processes.

\section{Material and methods}

\subsection{Material}

In the experiments, bananas sold in a local market in Bursa (imported from Ecuador) were used. The purchased bananas were first held in the refrigerator at $4{ }^{\circ} \mathrm{C}$ for 24 hours. Then, they were left in the laboratory for 3 hours until they reached the room temperature. First of all, bananas were sliced to $1 \mathrm{~cm}$ thickness as a disc shape. The diameter of the banana ranges from $2.5 \mathrm{~cm}$ to $3.5 \mathrm{~cm}$.

\subsection{Drying equipment and method}

Drying processes were carried out by a convective tunnel type drier found in Uludag University Heat Engineering Laboratory. The experimental setup is illustrated in Figure 1.

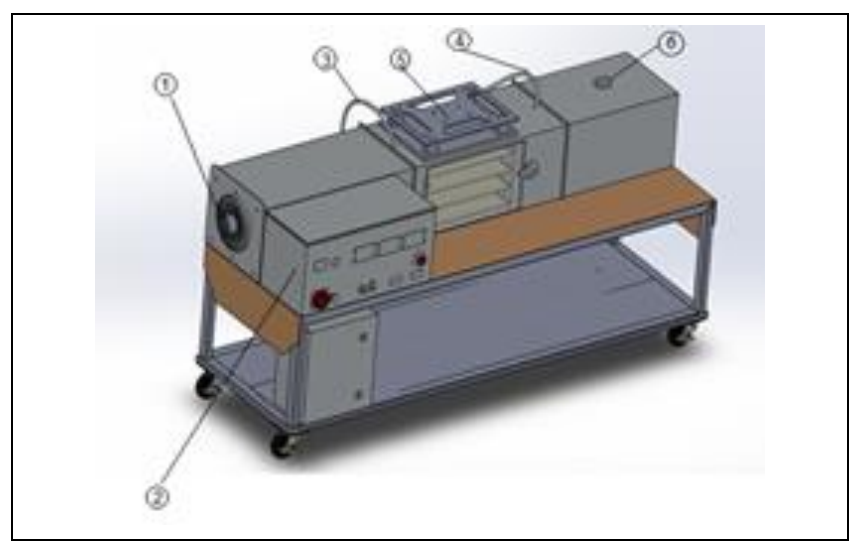

(1): Fan (air inlet). (2): Automatic control unit (velocity, temperature, humidity, and weight). (3)-(4): Temperature, humidity and velocity sensors, (5): Balance.

Figure 1. Experimental set up of tunnel type convective dryer.

\subsection{Determination of the initial moisture}

For determination of the initial moisture content, banana slices weighing $351 \pm 0.05 \mathrm{~g}$ were located in a dryer (Ogen, Turkey) and dehydrated at an air temperature of $75 \pm 0.3^{\circ} \mathrm{C}$. Drying was performed until the difference between the last two measurements became $1 \%$. The average primary moisture content (on wet basis) of the product was obtained to be as $72 \%$.

\subsection{Drying of banana}

The air temperatures $\left(40 \pm 0.3^{\circ} \mathrm{C}, 50 \pm 0.3^{\circ} \mathrm{C}\right.$ and $\left.60 \pm 0.3^{\circ} \mathrm{C}\right)$ and $0.5 \mathrm{~m} \mathrm{~s}^{-1}$ air velocity were used during experiments. In the meantime, the tunnel-type dryer was started until the steady regime was reached. The weight of empty tray $(33 \times 38 \mathrm{~cm})$ was measured and recorded. When the required provisions were ensured, the tray was placed in the dryer chamber. The drying chamber was constructed as a rectangular tunnel in $34.5 \mathrm{~cm}$ height, $228 \mathrm{~cm}$ lenght, $40 \mathrm{~cm}$ width. During the experiment, the change in the weight of the product was registered periodically with a digital scale (Kern, Germany) with a sensitivity of $0.05 \mathrm{~g}$. The experimental results were repeated three times. One side of the food was dried on the tray. Moisture is transferred from the surface of the product to the air while liquid diffusion reaches the surface from the inside product. Colour values ( $\mathrm{L}, \mathrm{a}$ and b) were measured in a colorimeter (PCE CSM 1-Germany with \pm 0.08 sensitivity), while temperature measurement $( \pm 0.5)$ was performed with temperature sensor (PCE 228-Germany). T-type thermocouple was used for center temperature measurement of the food. Center temperature was measured at the correct depth with a marker on the thermocouple and the measurement results were transferred to the data collector. and temperature value and colorimeter values (L, a, b) were recorded every half hour. For this, the average values of each colour parameter (L, a, b) were calculated by performing measurements from 5 different slices. Two trays of equal weight were prepared for each 
experiment at different temperatures. One tray was used only for weighing and colour measurement while the other was for the temperature measurement.

\subsection{Calculation of moisture content}

In order to determine the moisture content of the food material on dry and wet basis, Eq. 1 and Eq. 2 expressions are defined as:

$$
\begin{gathered}
M_{D B}=\left(\frac{W_{w}}{W_{d r}}\right)=\left(\frac{W_{-} W_{d r}}{W_{d r}}\right) \\
\% M_{W B}=\left(\frac{W_{w}}{W_{w}+W_{d r}}\right) \times 100
\end{gathered}
$$

Where $W$ is initial weight (g) of the food, $W_{w}$ is the water mass (g) in the food, and $W_{d r}$ is the mass (g) of the dry product [21]. The drying ratio (DR), which is the change in the moisture of the dried food per unit of time, can be expressed as follows:

$$
\mathrm{DR}=\left(\frac{M_{t}-M_{t+\Delta t}}{\Delta t}\right)
$$

Where $M_{t}$ is the moisture content of the food according to the dry basis [g water (g dry matter) ${ }^{-1}$ ] at $t$ time, and $M_{t+\Delta t}$ is the moisture content of the food according to the dry basis at the $t+\Delta t$ time [21]. Dimensionless moisture ratios (MR) is related to moisture content as:

$$
\mathrm{MR}=\frac{M_{t}-M_{e}}{M_{i}-M_{e}}
$$

Where $M_{e}$ [g water (g dry matter) ${ }^{-1}$ ] is the equilibrium moisture content at the end of drying, and $M_{i}$ [g water (g dry matter) ${ }^{-1}$ ] is the initial moisture content. In the study, the dimensionless moisture ratio was simplified, and $\mathrm{MR}=M_{t} / M_{i}$ was used [19][21].

\subsection{Total colour change}

The colour measurement help determine the freshness and quality of the product, the total colour deviation can be calculated using Eq. 5 [22].

$$
\Delta \mathrm{E}=\sqrt{(\Delta \mathrm{L})^{2}+(\Delta \mathrm{b})^{2}+(\Delta \mathrm{a})^{2}}
$$

$\Delta \mathrm{L}=\mathrm{L}_{\text {fresh }}-\mathrm{L}_{\text {dried }}$

$\Delta \mathrm{a}=\mathrm{a}_{\text {fresh }}-\mathrm{a}_{\text {dried }}$

$\Delta \mathrm{b}=\mathrm{b}_{\text {fresh }}-\mathrm{b}_{\text {dried }}$

\subsection{Mathematical modelling for the numerical analysis}

Fourier's and Fick's laws can be used to define the energy and mass balance in solids mathematically. While the heat from the air is conveyed to the food surface by convection, liquid in the product is transported to the surface by diffusion, and evaporation is observed. The energy conservation equation in solids based on Fourier's law can be given as follows;

$$
\rho c_{p}\left(\frac{\partial T}{\partial t}\right)+\nabla(-k \nabla T)=0
$$

Where $c_{p}$ is specific heat of food [J $\left(\mathrm{kg} \mathrm{K}^{-1}\right], k$ is the thermal conductivity of food [W $\left.(\mathrm{mK})^{-1}\right], \rho$ is density of food $\left[\mathrm{kg}\left(\mathrm{m}^{3}\right)^{-1}\right]$ and the mass conservation equation in solids based on Fick's law can be given as follows [23]:

$$
\frac{\partial C}{\partial t}+\nabla\left(-D_{e f f} \nabla M\right)=0
$$

Where $D_{\text {eff }}$ is effective diffusion coefficient $\left(\mathrm{m}^{2} \mathrm{~s}^{-1}\right)$ and $M$ is the moisture content [g water (g dry matter) ${ }^{-1}$ ].

\subsubsection{Initial and boundary conditions}

Beginning the first temperature and moisture content of food is $21{ }^{\circ} \mathrm{C}$ and $72 \%$.

\subsubsection{Heat transfer boundary conditions}

The surface boundary condition for heat transfer is given by:

$$
-\mathrm{n}(-k \nabla T)=\lambda h_{m}\left(M-M_{s}\right)+h_{t}\left(T-T_{s}\right)
$$

Where $h_{m}$ is mass transfer coefficient $\left(\mathrm{m} \mathrm{s}^{-1}\right), h_{t}$ is heat transfer coefficient [W $\left.\left(\mathrm{m}^{2} \mathrm{~K}\right)^{-1}\right], T_{S}$ is the drying air temperature $\left({ }^{\circ} \mathrm{C}\right)$ and $M_{S}$ is the moisture content of air [g water ( $\mathrm{g}$ dry matter) ${ }^{-1}$ ] Symmetry boundary condition for heat transfer is given by:

$$
\mathrm{n}(k \nabla T)=0
$$

\subsubsection{Mass transfer boundary conditions}

The surface boundary condition for mass transfer is written for balance between the liquid transfer from inside the food to the surface with diffusion and the vapour transfer from the food surface to the drying air.

$$
-\mathrm{n}(D \nabla M)=h_{m}\left(M-M_{s}\right)
$$

Symmetry boundary condition for mass transfer is given by:

$$
\mathrm{n}(D \nabla M)=0
$$

\subsection{Shrinkage dependent effective diffusivity}

The shrinkage effect was considered in the numerical model during drying. It is significant to examine the effect of the change in the product volume to calculate the diffusion coefficient. Shrinkage-dependent diffusivity is obtained by the following equation:

$$
\frac{D_{\text {ref }}}{D_{\text {eff }}}=\left(\frac{b_{0}}{b}\right)^{2}
$$

Where $D_{\text {ref }}$ is the reference diffusion coefficient $\left(\mathrm{m}^{2} \mathrm{~s}^{-1}\right)$ which is determined experimentally, and $b_{0}$ and $b$ are the halfthickness of the product at the beginning and time [11],[20]. In order to find the $D_{e f f}$ coefficient depending on the shrinkage effect given in Eq.12, the thickness-ratio variation must be calculated from Eq. 13 [24].

$$
b=b_{0}\left[\frac{\rho_{w}+M \rho_{s}}{\rho_{w}+M_{0} \rho_{s}}\right]
$$

Where $M$ is the moisture content of food [g water (g dry matter)-1] and $M_{0}$ is the initial moisture content of food [g water (g dry matter)-1].

\subsection{Determining of the heat and mass transfer coefficients}

The heat and mass transfer coefficients are estimated with well-known correlations in the literature. While the heat convection coefficient is obtained with the Nusselt $(\mathrm{Nu})$ number depending on the Reynolds $(R e)$ and Prandtl $(P r)$ dimensionless numbers, the mass transport coefficient is calculated with the Sherwood $(S h)$ number depending on the Reynolds and Schmidt $(S c)$ dimensionless numbers [11],[20],[25]. 


$$
\begin{aligned}
& \mathrm{Nu}=\frac{h_{T} L}{k}=0.664 \mathrm{Re}^{0.5} \operatorname{Pr}^{0.33} \\
& \mathrm{Sh}=\frac{h_{M} L}{D_{A B}}=0.664 \mathrm{Re}^{0.5} S c^{0.33}
\end{aligned}
$$

Where $h_{T}$ is the heat transfer coefficient [W $\left.\left(\mathrm{m}^{2} \mathrm{~K}\right)^{-1}\right], L$ characteristic length $(\mathrm{m})$ and $k$ is the thermal coefficient [W/mK].

\subsection{Data analysis}

In the experiment, the comparison was made with different drying models for the verification of the data obtained for different temperatures. Different empirical (Wang and Singh), and semi- theoretical (Lewis, Henderson and Pabis, Two Term, Midilli) models widely used in the literature were applied [26],[27]. These equations are presented in Table 1. Statistical calculations were made with the Sigma Plot program. The drying coefficients $\left(a, b, k, k_{0}, k_{1}, n\right)$ and the coefficients of determination $\left(\mathrm{R}^{2}\right)$, standard error of estimate (SEE) and chi-square $\left(\mathrm{x}^{2}\right)$ expressions, which are statistical parameters are calculated as [28]:

$$
\begin{aligned}
\mathrm{SEE} & =\sqrt{\frac{\sum_{i=1}^{N}\left(M R_{\text {exp }}-M R_{\text {pred }}\right)^{2}}{N-Z}} \\
\mathrm{x}^{2} & =\frac{\sum_{i=1}^{N}\left(M R_{\text {exp }}-M R_{\text {pred }}\right)^{2}}{N-Z}
\end{aligned}
$$

where $M R_{\text {exp }}$ is experimental moisture ratio, $M R_{\text {pred }}$ is the predicted moisture ratio, $N$ is the number of experimental data points and $z$ is the number of parameters in the model. To describe the most appropriate model, the $\mathrm{R}^{2}$ value should be close to 1 and SEE and $x^{2}$ values should be close to 0 [29].

Mean differences for colour parameter were tested by using an JMP programme (Tukey HSD test) at $1 \%$ levels of significance.

\subsection{Calculation of the effective diffusion coefficient and activation energy}

Fick's law of diffusion is widely used in drying processes. Eq. 18 is used to determine the diffusion coefficient [30]:

$$
\mathrm{MR}=\frac{8}{\pi^{2}} \sum_{n=0}^{\infty} \frac{1}{(2 n+1)^{2}} \exp \left(\frac{(2 n+1)^{2} \pi^{2} D_{\text {eff }} t}{4 L^{2}}\right)
$$

Where, $D_{\text {eff }}$ is the effective diffusion coefficient $\left(\mathrm{m}^{2} \mathrm{~s}^{-1}\right)$, and $L$ is the half-thickness (m) of the product. It can be explained by taking the initial term of the series given in Eq. 18 for different time periods [29].

$$
\mathrm{MR}=\frac{8}{\pi^{2}} \exp \left(-\frac{\pi^{2} D_{e f f} t}{4 L^{2}}\right)
$$

The inclination (i) is arranged by plotting of $\ln (\mathrm{MR})$ against drying time from Eq. 19.

$$
\mathrm{i}=\left(\frac{\pi^{2} D_{e f f}}{4 L^{2}}\right)
$$

Moisture bonding potential is used to define the drying characteristics of the product. This value is measured by the activation energy, which is the energy required to remove $1 \mathrm{~mol}$ moisture from the product [30]. The activation energy, $E_{0}$, which is the starting energy of chemical reactions, can be arranged by the following equation;

$$
D_{\text {eff }}=D_{0} \exp \left(-\frac{E_{0}}{R T}\right)
$$

Here $R$ is universal gas constant $\left[8.314 \times 10^{-3} \mathrm{~kJ}(\mathrm{~mol} . \mathrm{K})^{-1}\right], T$ is temperature $(\mathrm{K})$.

\subsection{Calculation of food shrinkage}

The shrinkage effect is widely observed in foods during the drying process. It affects the product property adversely. Therefore, it is important to consider this effect in the drying process.

The shrinkage coefficient $\left(S_{b}\right)$ can be obtained using the following equation [31].

$$
S_{b}=\left(1-\frac{V_{t}}{V_{0}}\right) \times 100
$$

\subsection{Uncertainity analysis of moisture content}

An error may occur in the experimental work due to the measuring devices. Therefore, it is necessary to determine the total error value by performing the uncertainty analysis of the measurement results. Overall uncertainity can be calculated using the next phrase;

$$
\begin{gathered}
W_{r}=\left[\left(\frac{\partial R}{\partial x_{1}} w_{1}\right)^{2}+\left(\frac{\partial R}{\partial x_{2}} w_{2}\right)^{2}+\cdots+\left(\frac{\partial R}{\partial x_{n}} w_{n}\right)^{2}\right]^{\frac{1}{2}} \\
e=\frac{W_{r}}{R}
\end{gathered}
$$

Where, $R\left(x_{1}, x_{2}, x_{3} \ldots x_{n}\right)$ is a function of independent variables,

\begin{tabular}{|c|c|c|c|}
\hline Model No & Name of Model & Model & Reference \\
\hline 1 & Lewis & $\mathrm{MR}=\exp (-\mathrm{kt})$ & [6] \\
\hline 2 & Henderson and Pabis & $\mathrm{MR}=\mathrm{aexp}(-\mathrm{kt})$ & [7] \\
\hline 3 & Two Term & $M R=a \exp \left(-k_{0} t\right)+b \exp \left(-k_{1} t\right)$ & [8] \\
\hline 4 & Wang and Singh & $\mathrm{MR}=1+\mathrm{at}+\mathrm{bt}^{2}$ & [9] \\
\hline 5 & Midilli & $M R=a \exp \left(-k t^{n}\right)+b t$ & [10] \\
\hline
\end{tabular}
$W_{r}$ overall uncertainity, $w_{1}, w_{2}, w_{3} \ldots w_{n}$ are error values of independent variables and e relative uncertainty [20],[32].

To calculate the moisture content of the food on a dry basis, the dry product and initial weight must be measured on a precision balance. Therefore, relative uncertainty that take place in the calculation of the moisture content will only depend on the weight. The uncertainty analysis equation associated with moisture content (Eq. 1) of the food product using Eq. 23-24 is expressed as;

Table 1. Constants and coefficients. 


$$
e_{m}=\left\{\left(\frac{\delta W}{W-W_{d r}}\right)^{2}+\left(\frac{W \delta W_{d r}}{\left(W-W_{d r}\right) W_{d r}}\right)^{2}\right\}^{\frac{1}{2}}
$$

Where $\delta W$ and $\delta W_{d r}$ is percentage error of weighing, $W_{d r}$ is dry weight of the food, $W$ is initial weight of the food. Using Eq. 25, the relative uncertainties for moisture content at 40-50 and 60 ${ }^{\circ} \mathrm{C}$ were obtained as $\pm 0.08 \%, \pm 0.09 \%$ and $\pm 0.12 \%$, respectively.

Sensitivity values and total uncertainty values of the measuring devices are given in Table 2 . While the uncertainty arising from the device is specified by the manufacturer among the characteristics of the device, the uncertainty arising from the incorrect reading of the person making the measurement is taken as experience [33].

\subsection{Numerical study}

The shape of the dried product is cylindrical. The twodimensional axisymmetric model approach, which is used to facilitate the solution of cylindrical models in a short time, was used in this study. A two-dimensional axisymmetric model was used to identify the simultaneous heat and mass transfer equations in the hot air convection drying process. Due to the axisymmetry of the food slabs, only one quarter of planer intersection was taken into consideration in the numerical method. It is observed in the literature that this model approach has been used in some numerical drying studies [20], [23],[38]. This model is established on the following hypotheses:

- Initially, the moisture content and the temperature value inside of the food were accepted to be homogeneous,

- The heat transfer in the food was considered by conduction, and mass transfer occured with diffusion,

- The heat transfer occured with convection from air to food and conduction inside the food, and the mass transfer took place with diffusion and convection from solid to air,

- $\quad$ The shrinkage effect was considered during the drying process,

- The radiation effect was neglected,

- The thermophysical properties of the air and food density were taken to be constant during the drying period.

First of all, to find the optimal mesh structure of the model, the mesh independence study was performed with a sensitivity of 0.001.1256 triangular mesh structure was found to be the most appropriate. Non-linear equations were solved using the finite element method (Comsol MultiphysicsTM 5.3, Comsol AB, Stockholm, Sweden [39] with boundary and initial conditions for the drying air. The equations were calculated with a tolerance value of 0.001 for 30 -minute time steps. The initial inlet conditions used in the analysis and the thermophysical characteristics of the food are demonstrated in Table 3.

\section{Results and discussion}

The moisture content (dry basis) under convective drying conditions is presented in Figure 2(a) at an drying air temperature 40,50 and $60{ }^{\circ} \mathrm{C}$ and $0.5 \mathrm{~m} / \mathrm{s}$ air velocity. It is clearly showed that drying at higher air temperatures results in lower moisture content. The moisture content values are found to be $1.49,0.84$ and 0.44 [g (g dry $\left.)^{-1}\right]$ at the drying air temperature of 40,50 and $60^{\circ} \mathrm{C}$ at the end of the drying process.

The drying rates of banana slices as a function of moisture content are presented in Figure2(b). The average drying rates for 40,50 , and $60{ }^{\circ} \mathrm{C}$ were calculated to be as $0.0031,0.0049$ and 0.0061 [g (g dry $\mathrm{min})^{-1}$ ], respectively.

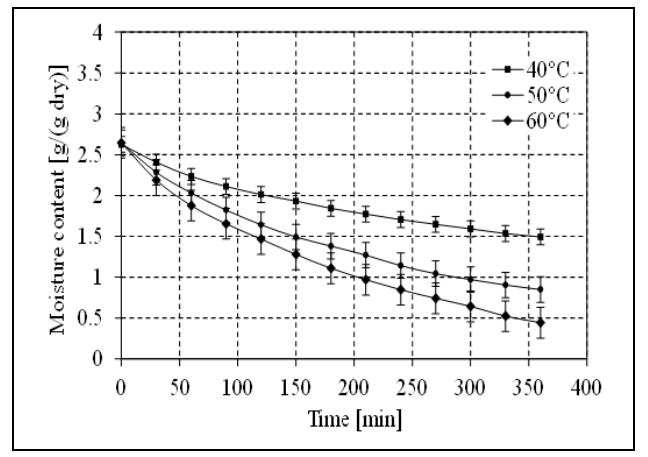

(a)

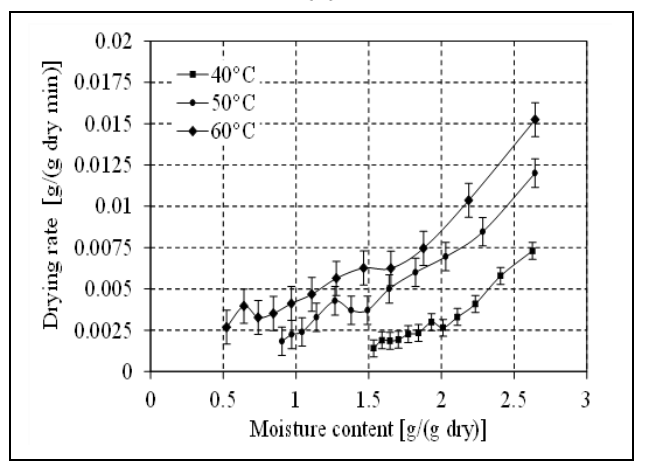

(b)

Figure 2. (a): Moisture profile against drying time. (b): Drying rate-moisture content relationship of banana for different drying temperatures $\left(40,50\right.$ and $\left.60^{\circ} \mathrm{C}\right)$ and at constant air velocity $0.5 \mathrm{~m} \mathrm{~s}^{-1}$.

It is clear that increasing drying air temperature rised drying rate.

From these figures, it can be stated that air temperature has a considerable effect on drying rates. Initial drying rate increased from 0.00730 [g (g dry min)-1] to 0.01524 [g (g dry min)-1] for increasing temperature from 40 to $60^{\circ} \mathrm{C}$ at $0.5 \mathrm{~m} \mathrm{~s}^{-1}$.

As it can be seen in Figure 2, the invariable rate interval was not discovered in the drying curved but moisture content decreased substantially during the initial stages of drying because the liquid on the surface of the food has evaporated quickly. It was observed that an increase occurred in the drying rate at a higher temperature.

The temperature increase of $10{ }^{\circ} \mathrm{C}$ increased the drying rate by an average of 1.3 times. It is observed that drying occurs in the falling rate period for 3 temperature values. This region cannot be observed since the drying phase is very short at the constant rate in the drying of bananas. The actual drying process occurs in the falling rate period when the diffusion effect is observed [13]. Since the moisture content in the product decreases throughout the drying process at different temperatures, the drying rate also decreases in time. The decreased drying rate trend is also compatible with the results of some studies in the literature [11],[35]-[37]. 
Table 2. Total uncertainty values of the measuring devices used in the drying test.

\begin{tabular}{|c|c|c|c|c|}
\hline Device & Parameter & Accuracy $( \pm)$ & Uncertainty $( \pm)$ & Overall uncertainty $( \pm)$ \\
\hline \multirow{3}{*}{ Dryer } & Air temperature & $0.3^{\circ} \mathrm{C}$ & 0.1 & 0.3162 \\
\hline & Air velocity & $0.1 \mathrm{~m} \mathrm{~s}^{-1}$ & 0.1 & 0.1414 \\
\hline & Air relative humidity & $\% 1.8(\mathrm{RH})$ & 0.01 & 0.0205 \\
\hline Temperature sensor & Food temperature & $0.5^{\circ} \mathrm{C}$ & 0.1 & 0.5099 \\
\hline Digital scale & Food weight & $0.05 \mathrm{~g}$ & 0.01 & 0.0509 \\
\hline Colorimeter & Food colour change & 0.08 & 0.1 & 0.1281 \\
\hline
\end{tabular}

Table 3. Thermophysical properties and experimental drying conditions of the banana [11],[25],[34].

\begin{tabular}{|c|c|}
\hline Parameter & Value \\
\hline Air velocity $\left[\mathrm{m}(\mathrm{s})^{-1}\right]$ & 0.5 \\
\hline Food temperature $\left({ }^{\circ} \mathrm{C}\right)$ & 21 \\
\hline Food density $\left[\mathrm{kg}(\mathrm{m})^{-3}\right]$ & 980 \\
\hline Food moisture content (\% w.b.) & 72 \\
\hline Air moisture content (\%) & $16.1\left(40^{\circ} \mathrm{C}\right)-10.7\left(50^{\circ} \mathrm{C}\right)-8.2\left(60^{\circ} \mathrm{C}\right)$ \\
\hline Thermal conductivity of food [W $\left.(\mathrm{mK})^{-1}\right]$ & $0.006 \mathrm{M}+0.120$ \\
\hline Specific heat [J $\left.(\mathrm{kgK})^{-1}\right]$ & $0.811 \mathrm{M}^{2}-24.75 \mathrm{M}+1742$ \\
\hline Heat of vaporization $\left[\mathrm{kj}(\mathrm{kg})^{-1}\right]$ & 2454 \\
\hline Water density $\left[\mathrm{kg}(\mathrm{m})^{-3}\right]$ & 998 \\
\hline
\end{tabular}

M, Moisture content g ( g dry $^{-1}$

Figure 2 also demonstrates that drying occurs in the falling rate period for different air temperatures. In the falling ratio period, the drying rate of banana is appeared a sharp decline at the early stage of the drying process. It is appeared diffusion effect in this period. As soon as the water has been transported, the drying rate tends progressively to decrease [13],[17].

\subsection{Validation study}

The numerical model was verified by comparing the moisture content (on wet basis) and temperature values obtained from experiments. Figure 3 presents the variation of the average moisture content (on wet basis) values obtained from the experiment and the numerical analysis (with shrinkage) for different drying air temperatures. A difference of approximately $2.2 \%\left(40^{\circ} \mathrm{C}\right), 2.9 \%\left(50^{\circ} \mathrm{C}\right)$ and $6.8 \%\left(60^{\circ} \mathrm{C}\right)$ was observed during drying period. Simultaneously, numerical analysis was performed for without shrinkage case. The results of the numerical model with-shrinkage and without-shrinkage cases are also presented in Figure 3(b). For example, approximately $2 \%$ difference was obtained for the numerical results of with-shrinkage and without-shrinkage cases for the moisture content of the food.

Food temperature for different air temperatures during drying interval is presented in Figure 4. The average difference between the center temperature values of the product obtained from the experiments and numerical simulation was found to be 7,8 and $5 \%$ for air temperatures of $40{ }^{\circ} \mathrm{C}, 50{ }^{\circ} \mathrm{C}$ and $60^{\circ} \mathrm{C}$, separately. Using the Comsol MultiphysicsTM 5.3, the temperatures were obtained at different location of food.

Figure $4(\mathrm{~b})$ indicates the predicted food temperatures at surface $(x / b=1)$, central $(x / b=0)$ and midpoint $(x / b=0.5)$. Center temperature measured experimentally was also plotted in Figure 4(b).

Numerical results (center, surface and midpoint temperatures) show close agreement with each other. As a result, it can be said that there is a suitable coherency between numerical and experimental solutions. Since the moisture distribution inside food is variable, it is difficult to calculate moisture content experimentally. the center. If the dry state cannot be provided, liquid remaining inside food causes to form microorganisms in the food [20]. However, the moisture distribution in the food can be estimated by using simulation. The amount of evaporation from the food surface is higher when compared to the center.

\subsection{Colour measurement results}

Figure 5 represents variation with moisture content of the measured colour parameter values $\mathrm{L}, \mathrm{a}$, and $\mathrm{b}$ for 3 diversified air temperatures $\left(40,50\right.$ and $\left.60^{\circ} \mathrm{C}\right)$. According to these results, it can be said that as the air temperature raises and moisture content decreases, the brightness (L) value of the food decreases remarkably. It was observed that for each air temperature, the value $a$ of the food increased and the value $b$ decreased from Figure 5 and Table 4.

It can also be mentioned that the redness (a) of the food increased while the yellowness (b) decreased during drying period. Equivalent results were obtained in the literature for increase of air temperature in banana drying [13].

When a (red colour) parameter exceeds the value of +3 , the food begins to lose yellowness and greenness. If drying is continued, an increase is seen in the redness of the food. This phenomenon is caused by the separation between chlorophyll and carotenoid pigments [22]. Some results obtained in the drying of different foods in the literature are as follows; it was viewed that the $L$ value decreased and $a$ and $b$ increased with the temperature in bean drying [40]. Also, it was discovered that $\mathrm{L}, \mathrm{a}$, and $\mathrm{b}$ values decreased in date palm and tomato drying [37].

The total colour changes for the food at 40,50 and $60{ }^{\circ} \mathrm{C}$ were calculated to be $24.9 \pm(1.56), 29.1 \pm(2.42)$ and $31.27 \pm(2.58)$, respectively.

According to these results, it is seen that the colour change value increases as the drying air temperature rises. Because of browning effect, L parameter increases with temperature. It can be said that total colour changes increase is mainly caused by the change in the parameters of brightness and redness [41]. As a result, it can be considered that the air temperature is especially effective on the $\mathrm{L}$, $\mathrm{a}$, and $\mathrm{b}$ colour parameters in the tunnel-type convective dryer. 


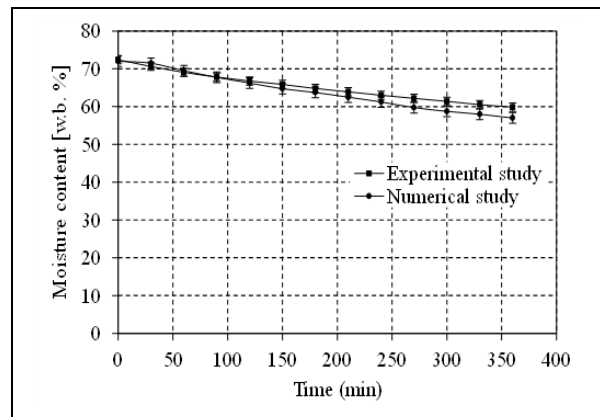

(a)

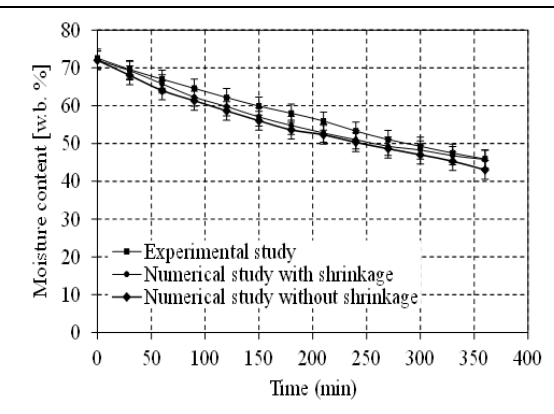

(b)

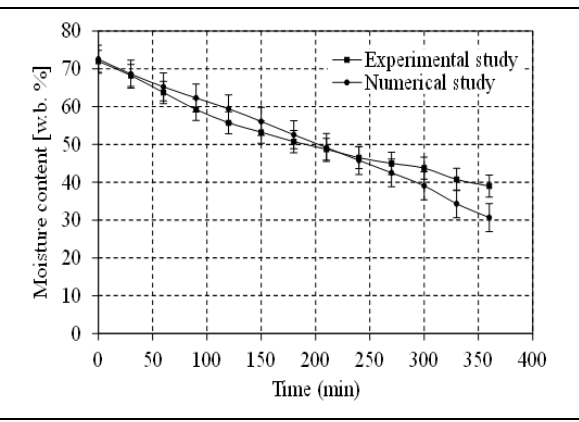

(c)

Figure 3. Moisture content (on wet basis)- time relationship of banana at different air temperatures $\left(\mathrm{a}-40{ }^{\circ} \mathrm{C}, \mathrm{b}-50^{\circ} \mathrm{C}, \mathrm{c}-60^{\circ} \mathrm{C}\right)$ and air velocity of $0.5 \mathrm{~m} \mathrm{~s}^{-1}$.

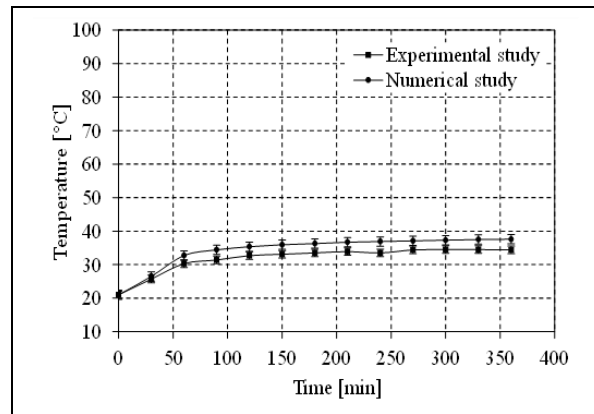

(a)

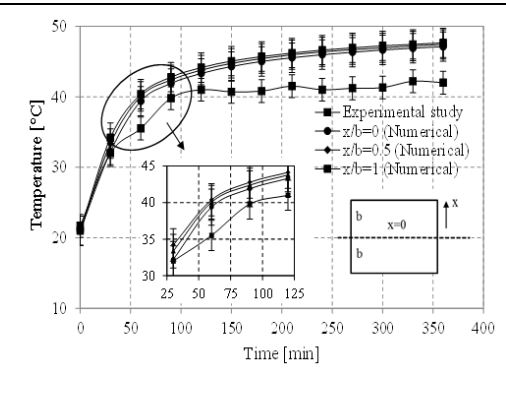

(b)

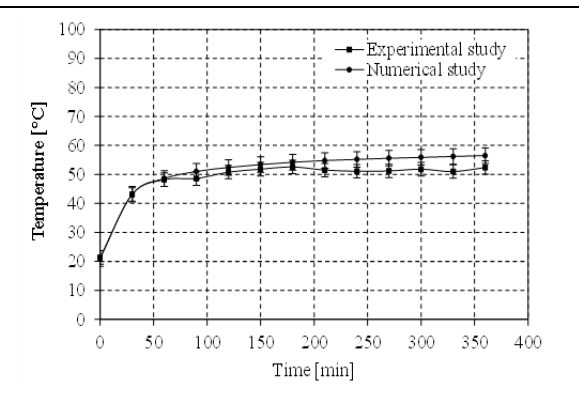

(c)

Figure 4. Temperature-time relationship of banana slice for air temperatures $\left(\mathrm{a}-40{ }^{\circ} \mathrm{C}, \mathrm{b}-50^{\circ} \mathrm{C}, \mathrm{c}-60^{\circ} \mathrm{C}\right)$ and air velocity of $0.5 \mathrm{~m} \mathrm{~s}-1$.

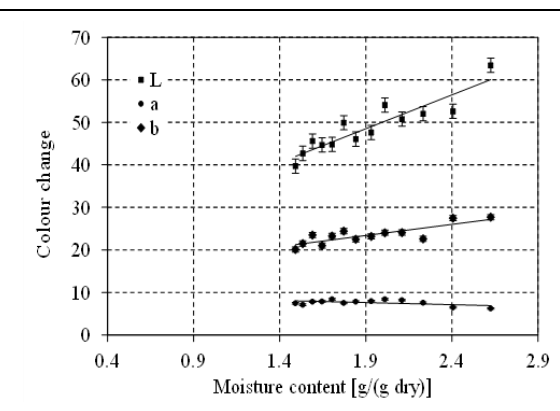

(a)

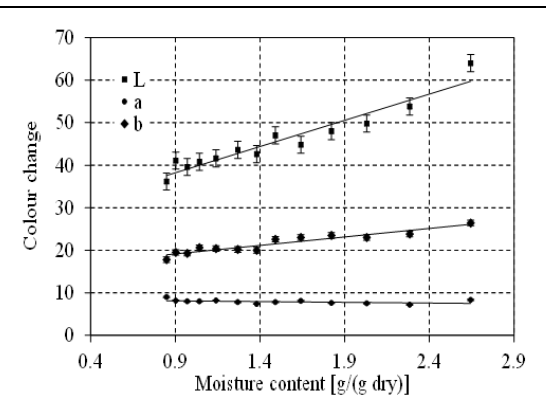

(b)

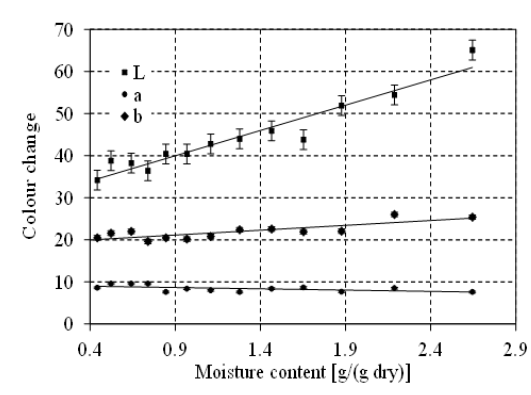

(c)

Figure 5. Colour change-moisture content (dry basis) relationship for different air temperatures $\left(\mathrm{a}-40{ }^{\circ} \mathrm{C}, \mathrm{b}-50{ }^{\circ} \mathrm{C}, \mathrm{c}-60^{\circ} \mathrm{C}\right)$ and air velocity of $0.5 \mathrm{~m} \mathrm{~s}^{-1}$

Table 4. Colour parameter $(L, a, b)$ and colour deviation values of fresh and dry banana slices.

\begin{tabular}{clcccc}
\hline & Parameter & \multicolumn{1}{c}{$\mathrm{L}^{* *}$} & $\mathrm{a}^{* *}$ & $\mathrm{~b}^{* *}$ & $\Delta \mathrm{E}^{* *}$ \\
\hline $40^{\circ} \mathrm{C}$ & Fresh & $63.4 \pm(0.97)^{\mathrm{a}}$ & $6.24 \pm(0.31)^{\mathrm{a}}$ & $27.7 \pm(0.6)^{\mathrm{a}}$ & $24.9 \pm(1.56)^{\mathrm{a}}$ \\
& Dried & $39.7 \pm(1.98)^{\mathrm{b}}$ & $7.44 \pm(0.37)^{\mathrm{a}}$ & $20.1 \pm(0.5)^{\mathrm{a}}$ & \\
$50^{\circ} \mathrm{C}$ & Fresh & $64 \pm(2.12)^{\mathrm{a}}$ & $8.34 \pm(0.31)^{\mathrm{a}}$ & $26.42 \pm(0.19)^{\mathrm{a}}$ & $29.1 \pm(2.42)^{\mathrm{a}}$ \\
& Dried & $36.1 \pm(2.32)^{\mathrm{b}}$ & $9 \pm(0.96)^{\mathrm{a}}$ & $17.8 \pm(0.94)^{\mathrm{a}}$ & \\
$60^{\circ} \mathrm{C}$ & Fresh & $65.07 \pm(1.83)^{\mathrm{a}}$ & $7.6 \pm(0.51)^{\mathrm{a}}$ & $25.4 \pm(0.4)^{\mathrm{a}}$ & $31.27 \pm(2.58)^{\mathrm{a}}$ \\
& Dried & $34.2 \pm(1.93)^{\mathrm{b}}$ & $8.6 \pm(0.74)^{\mathrm{a}}$ & $20.5 \pm(0.5)^{\mathrm{a}}$ & \\
\hline
\end{tabular}

$\mathrm{L}$, brightness; a, red colour value; $\mathrm{b}$, yellow colour value; $\Delta \mathrm{E}$, colour deviation.

${ }^{* *} \mathrm{P}<0.01$; Column mean values with different superscripts are significantly different. 


\subsection{Drying characteristic of banana}

Moisture contents were fitted to the five drying models. The statistical results obtained from these models for $\mathrm{P}<0.001$ were presented collectively in Table 5.

For the air temperature of $40{ }^{\circ} \mathrm{C}, \mathrm{R}^{2}$, SEE, and $\mathrm{x}^{2}$ values in the Two Term and Midilli model were calculated to be 0.99, 0.0021, and $4.5 \times 10^{-6}$ and $0.99,0.0029$ and $8.4 \times 10^{-6}$, respectively. For the air temperature of $50{ }^{\circ} \mathrm{C}$, the $\mathrm{R}^{2}$, SEE, and $\mathrm{x}^{2}$ values in the Midilli model were calculated to be $0.99,0.0041$ and $1.6 \times 10^{-5}$, respectively. For $60^{\circ} \mathrm{C}$, the $\mathrm{R}^{2}$, SEE, and $\mathrm{x}^{2}$ values in the Midilli model were calculated to be $0.99,0.0038$ and $1.4 \times 10^{-5}$, respectively. The thin layer model where $\mathrm{R}^{2}$ value is the closest to 1 and SEE, $x^{2}$ values is the smallest is the Midilli model. According to these results, it can be said that the Midilli model gives better predictions among the other models and is the most appropriate model.

\subsection{Calculation of the effective diffusion coefficient activation energy and shrinkage coefficient}

From Eq. 6, the effective diffusion coefficient for the air temperatures of 40,50 and $60^{\circ} \mathrm{C}$ was obtained to be $2.02 \times 10^{-10}$, $5.05 \times 10^{-10}$ and $8.08 \times 10^{-10} \mathrm{~m}^{2} \mathrm{~s}^{-1}$, respectively. In most of the banana drying studies notified in the literature, it was shown that the effective diffusion coefficients varied between $10^{-9}$ and $10^{-11} \mathrm{~m}^{2} \mathrm{~s}^{-1}$ [11],[13]. The relationship between the effective diffusion coefficient and the air temperature was found to be Deff $=0.303 T-10.1$ and $R^{2}=1$ (Figure 6(b). It can be seen that increasing the air temperature causes an increase in the effective diffusion coefficient [11]. The activation energy was computed using the slope of the In(Deff)-1/T graph shown in Figure 6(a) and was found to be $61.1 \mathrm{~kJ}(\mathrm{~mol})^{-1}$. The activation energies of most foods vary from $12.7 \mathrm{~kJ}(\mathrm{~mol})^{-1}$ to $110 \mathrm{~kJ}(\mathrm{~mol})$ 1 [42].

The shrinkage effect should be considered to understand the drying kinetics of the food. Samples dried at each temperature value $\left(40,50\right.$ and $\left.60^{\circ} \mathrm{C}\right)$ were used for the examination of the shrinkage effect occurring in the food. The shrinkage coefficients in the food for the drying air temperatures of 40, 50 and $60{ }^{\circ} \mathrm{C}$ were found to be approximately $23 \%, 32 \%$, and $40 \%$ respectively. The volumetric change of approximately $8.5 \%$ occurred in the food at every $10{ }^{\circ} \mathrm{C}$ temperature increase. Figure 7 illustrates the relationship between the moisture content and the shrinkage coefficient. According to these results, it can be said that the drying air temperature is an effective argument on the food shrinkage [43].

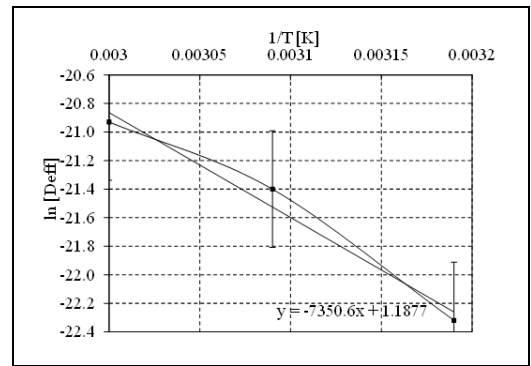

(a)

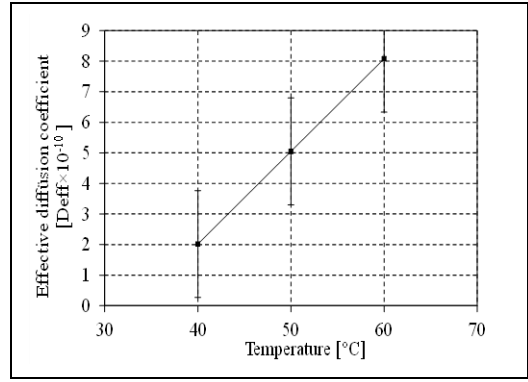

(b)

Figure 6. (a): The variation of effective diffusion coefficient with temperature (1/T). (b): Effective diffusion coefficient versus air temperature.

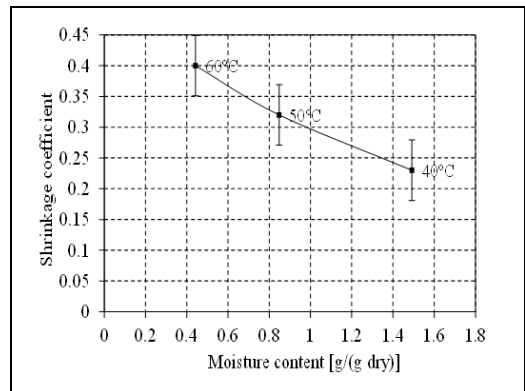

Figure 7. Experimental moisture content-shrinkage coefficient relationship of banana at varied air temperatures and air velocity of $0.5 \mathrm{~m} \mathrm{~s}^{-1}$.

Table 5. Statistical parameter values and coefficients.

\begin{tabular}{|c|c|c|c|c|c|c|c|c|c|}
\hline \multirow[b]{2}{*}{ Model } & \multicolumn{3}{|c|}{$\begin{array}{c}40{ }^{\circ} \mathrm{C} \\
\text { Constants and coefficients }\end{array}$} & \multicolumn{3}{|c|}{$\begin{array}{c}50^{\circ} \mathrm{C} \\
\text { Constants and coefficients }\end{array}$} & \multicolumn{3}{|c|}{$\begin{array}{c}60{ }^{\circ} \mathrm{C} \\
\text { Constants and coefficients }\end{array}$} \\
\hline & $R^{2}$ & $S E E$ & $x^{2}$ & $R^{2}$ & $S E E$ & $x^{2}$ & $R^{2}$ & $S E E$ & $x^{2}$ \\
\hline 1 & 0.94 & 0.0315 & $1.0 \times 10^{-3}$ & 0.98 & 0.0274 & $8.0 \times 10^{-4}$ & 0.99 & 0.0171 & $3.0 \times 10^{-4}$ \\
\hline 2 & 0.97 & 0.0223 & $5.0 \times 10^{-3}$ & 0.99 & 0.0213 & $5.0 \times 10^{-4}$ & 0.99 & 0.0137 & $2.0 \times 10^{-4}$ \\
\hline 3 & 0.99 & 0.0021 & $4.5 \times 10^{-6}$ & 0.99 & 0.0047 & $2.1 \times 10^{-5}$ & 0.99 & 0.0084 & $7.0 \times 10^{-5}$ \\
\hline 4 & 0.99 & 0.0119 & $1.0 \times 10^{-4}$ & 0.99 & 0.0160 & $3.0 \times 10^{-4}$ & 0.99 & 0.0224 & $5.0 \times 10^{-4}$ \\
\hline 5 & 0.99 & 0.0029 & $8.4 \times 10^{-6}$ & 0.99 & 0.0041 & $1.6 \times 10^{-5}$ & 0.99 & 0.0038 & $1.4 \times 10^{-5}$ \\
\hline 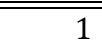 & \multicolumn{2}{|c|}{$\mathrm{k}=1.8 \times 10^{-3}$} & & \multicolumn{2}{|c|}{$\overline{\mathrm{k}=3.5 \times 10^{-2}}$} & & \multicolumn{2}{|c|}{$\mathrm{k}=4.9 \times 10^{-3}$} & \\
\hline 2 & \multicolumn{2}{|c|}{$\mathrm{k}=1.6 \times 10^{-3}$} & $a=9.5 \times 10^{-1}$ & \multicolumn{2}{|c|}{$\mathrm{k}=3.3 \times 10^{-3}$} & $a=9.5 \times 10^{-1}$ & \multicolumn{2}{|c|}{$\mathrm{k}=4.7 \times 10^{-3}$} & $a=9.7 \times 10^{-1}$ \\
\hline 3 & \multirow{2}{*}{\multicolumn{2}{|c|}{$\begin{array}{c}\mathrm{a}=1.4 \times 10^{-2} \\
\mathrm{k}_{0}=1.5 \times 10^{-2}\end{array}$}} & $\mathrm{~b}=8.5 \times 10^{-1}$ & \multicolumn{2}{|c|}{$a=1.7 \times 10^{-1}$} & $\mathrm{~b}=8.2 \times 10^{-1}$ & \multicolumn{2}{|c|}{$\mathrm{a}=9.4 \times 10^{-1}$} & $\mathrm{~b}=5.0 \times 10^{-2}$ \\
\hline & & & $\mathrm{k}_{1}=1.1 \times 10^{-3}$ & \multirow{2}{*}{\multicolumn{2}{|c|}{$\begin{array}{l}\mathrm{k}_{0}=1.6 \times 10^{-2} \\
\mathrm{a}=-3.3 \times 10^{-3}\end{array}$}} & $\mathrm{k}_{1}=2.7 \times 10^{-2}$ & \multicolumn{2}{|c|}{$\mathrm{k}_{0}=4.6 \times 10^{-3}$} & $\mathrm{k}_{1}=1.2 \times 10^{-1}$ \\
\hline 4 & \multicolumn{2}{|c|}{$a=-2.0 \times 10^{-3}$} & $\mathrm{~b}=2.4 \times 10^{-6}$ & & & $\mathrm{~b}=4.3 \times 10^{-6}$ & \multicolumn{2}{|c|}{$a=-3.9 \times 10^{-3}$} & $\mathrm{~b}=4.8 \times 10^{-6}$ \\
\hline 5 & \multicolumn{2}{|c|}{$a=1.0 \times 10^{0}$} & $\mathrm{~b}=2.0 \times 10^{-4}$ & \multicolumn{2}{|c|}{$a=1.0 \times 10^{0}$} & $\mathrm{~b}=8.0 \times 10^{-5}$ & \multirow{2}{*}{\multicolumn{2}{|c|}{$\begin{array}{l}a=1.0 \times 10^{0} \\
n=7.8 \times 10^{-1}\end{array}$}} & $\mathrm{~b}=-3.0 \times 10^{-4}$ \\
\hline & \multicolumn{2}{|c|}{$\mathrm{n}=7.7 \times 10^{-1}$} & $\mathrm{k}=7.1 \times 10^{-3}$ & \multicolumn{2}{|c|}{$\mathrm{n}=8.5 \times 10^{-1}$} & $\mathrm{k}=8.3 \times 10^{-3}$ & & & $\mathrm{k}=1.2 \times 10^{-2}$ \\
\hline
\end{tabular}

$\mathrm{R}^{2}$,coefficient of determination; SEE, Standard error of estimate; $\mathrm{x}^{2}$, chi-square;

$\mathrm{k}, \mathrm{k}_{0}, \mathrm{k}_{1}$, drying constant ( $\left.\min ^{-1}\right) ; \mathrm{a}, \mathrm{b}$, coefficients; $\mathrm{n}$, drying constant. 


\section{Conclusions}

The drying kinetics of banana was looked into in this study. Some remarkable results obtained from the study can be briefly summarized as follows;

It was observed that the air temperature have a great effect on the drying rate. The drying of bananas occurred only in the falling rate period for all temperatures and there is no constant rate period of drying.

As a result of the nonlinear regression analysis, it can be said that the best model in describing the drying kinetics of banana is the Midilli model.

It was detected that for drying air temperatures, the $\mathrm{L}$ and $\mathrm{b}$ value decreased, a value increased. The maximum darkening of the food colour occurred at $60{ }^{\circ} \mathrm{C}$. Furthermore, total colour change of the food were calculated, and the maximum deviation occurred with $31.27 \pm 2.58$ at $60^{\circ} \mathrm{C}$. The closest conditions to the fresh food were obtained at $60{ }^{\circ} \mathrm{C}$ for yellowness and at $50{ }^{\circ} \mathrm{C}$ for redness.

The effective diffusion coefficients of 40,50 and $60{ }^{\circ} \mathrm{C}$ air temperatures were found to be $2.02 \times 10^{-10}, 5.05 \times 10^{-10}$, and $8.08 \times 10^{-10} \mathrm{~m}^{2} \mathrm{~s}^{-1}$, respectively. According to this result, it was determined that the drying air temperature was an efficient parameter on the effective diffusion coefficient. Moisture diffusivity in agricultural products is an important feature in areas where mass transfer is effective, such as drying and storage. The activation energy of the banana was computed to be $61.1 \mathrm{~kJ}(\mathrm{~mol})^{-1}$.

The shrinkage coefficient was accounted for the change in the food volume, and the maximum volumetric change was indicated with $40 \%$ at $60^{\circ} \mathrm{C}$ air temperature. Shrinkage coefficient was increased by increasing air temperature. It can be said that air temperature is an effective parameter on drying. The reduction in food volume during drying is important in terms of transportation costs.

Experimental and numerical solutions were compared and it is shown that it is a good coherence between experimental and numerical results. The numerical model can be used to determine the moisture and temperature distribution at any location inside food during drying. Therefore, it can become possible to prevent this deterioration by using a numerical solution when the moisture distribution inside the food cannot be determined experimentally.

It is suggested that investigation into drying of food should be carried out with hot air and infrared dryers. The effect of exergy efficiency on drying can be examined. In addition, the numerical method used in this study will provide useful data on food drying for both academic and industrial users.

\section{Nomenclature}

C : Colour parameter,

$c_{p}:$ Specific heat $\left[\mathrm{kJ}\left(\mathrm{kgK}^{-1}\right]\right.$,

$D_{A B}$ : Binary diffusion coefficient (water-air) $\left[\mathrm{m}^{2}(\mathrm{~s})^{-1}\right]$,

$D_{\text {eff }}$ : $\quad$ effective moisture diffusivity $\left[\mathrm{m}^{2}(\mathrm{~s})^{-1}\right]$,

$D R$ : $\quad$ Drying rate [g water (g dry matter $\mathrm{min})^{-1}$ ],

$D_{o}$ : Coefficient,

$E_{o}:$ Aktivation energy [kJ (mol)-1],

$h_{m}: \quad$ Mass transfer coefficient [m (s) $\left.{ }^{-1}\right]$,

$h_{t}: \quad$ Heat transfer coefficient $\left[\mathrm{W}\left(\mathrm{m}^{2} \mathrm{~K}\right)^{-1}\right]$,

$k$ : Thermal conductivity of food [W $\left.(\mathrm{mK})^{-1}\right]$,

$L \quad$ : Lenght (m),

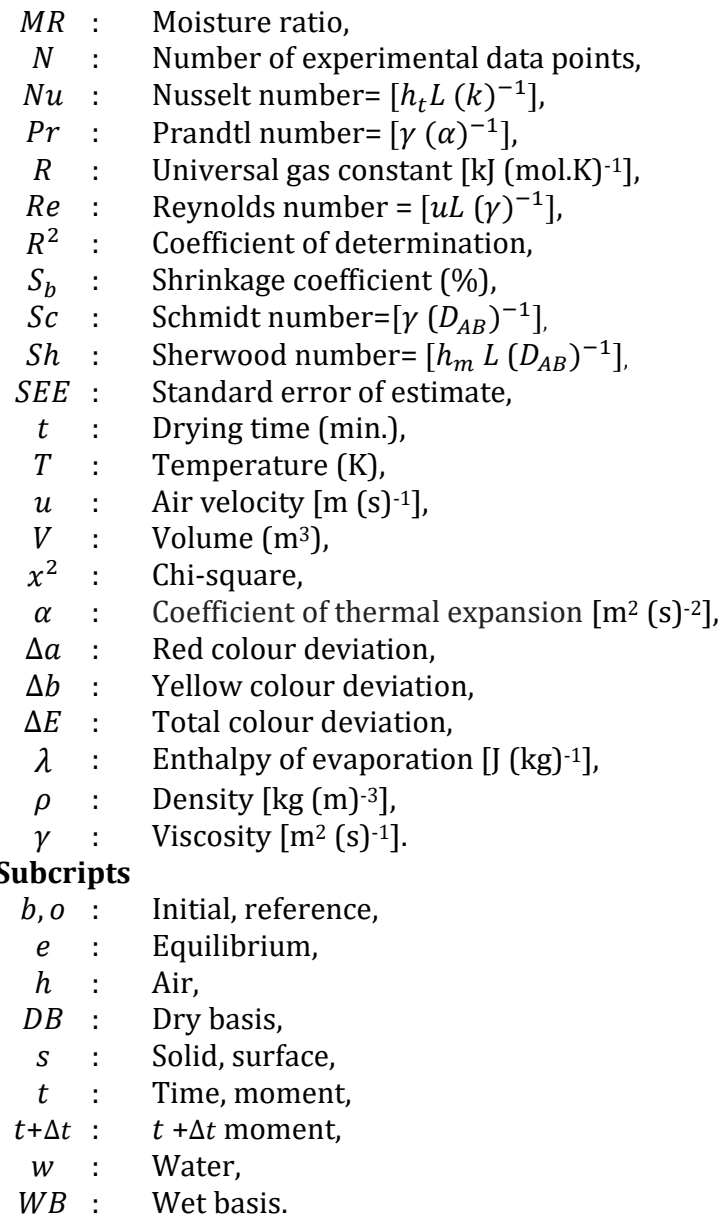

\section{References}

[1] Zhan-Wu S, Wei-Hong M, Zhi-Qiang J, Yang B, Zhi-Gao S "Investigation of dietary fiber, protein, vitamin $\mathrm{E}$ and other nutritional compounds of banana flower of two cultivars grown in China". African Journal of Biotechnology, 9(25), 3888-3895, 2010.

[2] Alibas, I. "Characteristics of chard leaves during microwave, convective, and combined microwave convective drying". Drying Technology, 24(1), 1425-1435, 2006.

[3] Barati E. Esfahani JA. "A new solution approach for simultaneous heat and mass transfer during convective drying of mango". Journal of Food Engineering, 102(4), 302-309, 2011.

[4] Heldman DR, Hartel RW. Principles of food Processing. $1^{\text {st }}$ Ed. Gaithersburg, Aspen Publishers, 1998.

[5] Lima AGB. Queiroz MR, Nebra SA. "Simultaneous moisture transport and shrinkage during drying solids with ellipsoidal configuration". Chemical Engineering Journal, $86,83-85,2002$.

[6] Lewis WK, "The rate of drying of solid materials". Journal of Industrial \& Engineering Chemistry, 13(5), 427-432, 1921.

[7] Henderson SM, Pabis S. "Grain drying theory I: temperature effect on drying coefficient". Journal of Agricultural Engineering Research, 6(3), 169-174, 1961.

[8] Madamba PS, Driscoll RH, Buckle KA. "The thin layer drying characteristics of garlic slices". Journal of Food Engineering, 29(1), 75-97, 1996. 
[9] Wang CY, Singh RP. "A single layer drying equation for rough rice". American Society of Agricultural Engineers, 78(3001), 33, 1978.

[10] Midilli A, Kucuk H, Yapar Z. "A new model for single layer drying". Drying Technology, 20(7),1503-1513, 2002.

[11] Karim MA, Hawlader MNA. "Mathematical modelling and experimental investigation of tropical fruits drying". International Journal of Heat and Mass Transfer, 48(23), 4914-4925, 2005.

[12] Samadi SY, Ghobadian B, Najafi G, Motevali A. "Potential saving in energy using combined heat and power technology for drying agricultural products (banana slices)". Journal of the Saudi Society of Agricultural Sciences, 13(2), 174-182, 2014.

[13] Thuwapanichayanan R, Prachayawarakorn S, Kunwisawa J, Soponronnarit S, "Determination of effective moisture diffusivity and assessment of quality attributes of banana slices during drying". LWT - Food Science and Technology, 44(6), 1502-1510, 2011.

[14] Baini R, Langrish TAG. "An assessment of the mechanisms for diffusion in the drying of bananas". Journal of Food Engineering, 85, 201-214, 2008.

[15] Nguyen HM, Price EW. "Air drying of banana: Influence of experimental parameters, slab thickness, banana maturity and harvesting season". Journal of Food Engineering, 79(1), 200-207, 2007.

[16] Fernando WJN, Low HC, Ahmad AL. "Dependence of the effective diffusion coefficient of moisture with thickness and temperature in convective drying of sliced materials, A study on slices of banana, cassava and pumpkin". Journal of Food Engineering, 102(4), 310-316, 2011.

[17] Silva WP, Silva CMDPS, Gomes JP. "Drying description of cylindrical pieces of bananas in different temperatures using diffusion models". Journal of Food Engineering, $117,417-424,2013$.

[18] Joardder MUH, Kumar C, Karim MA. “Multiphase transfer model for intermittent microwave-convective drying of food: Considering shrinkage and pore evolution". International Journal of Multiphase Flow, 95, 101-119, 2017.

[19] Saha B, Bucknall M, Arcot J, Driscoll R. "Derivation of two layer drying model with shrinkage and analysis of volatile depletion during drying of banana". Journal of Food Engineering, 226, 42-52, 2018.

[20] Kumar C, Millar GJ, Karim MA. "Effective diffusivity and evaporative cooling in convective drying of food material". Drying Technology, 33, 227-237, 2015.

[21] Doymaz I. "Thin-layer drying behaviour of mint leaves". Journal of Food Engineering, 74(3), 370-375, 2006.

[22] Maskan M. "Microwave/air and microwave finish drying of banana". Journal of Food Engineering, 44, 71-78, 2000.

[23] Sabarez HT. "Computational modelling of the transport phenomena occurring during convective drying of prunes". Journal of Food Engineering, 111(2), 279-288, 2012.

[24] Desmorieux H, Moyne C. In Drying 92. Editors: Mujumdar AS. Analysis of dryer performance for tropical foodstuffs using the characteristic drying curve concept, 834-843, Amsterdam, Elsevier, 1992.

[25] Cengel YA. Heat Transfer: A Practical Approach. $2^{\text {nd }}$ ed. Boston, USA, McGraw-Hill, 2002.
[26] Hassan Beygi SR, Aghbashlo M. Kianmehr MH, Massah J. "Drying characteristics of walnut (Juglans regia L,) during convection drying". International Agrophysics, 23(2), 129-135, 2009.

[27] Kashaninnejad M, Mortazavi A, Safekordi A, Tabil LG. "Thin-layer characteristics and modeling of pistachionuts". Journal of Food Engineering, 78, 98-108, 2007.

[28] Goyal RK, Kingsly ARP, Mainkanthan MR, Ilyas SM. "Mathematical modeling of thin- layer drying kinetics of plum in a tunnel dryer". Jourrnal of Food Engineering, 79(1), 176-180, 2007.

[29] Pangavhane DR, Sawhney PN, Sarsavadia PN. "Effect of various dipping pretreatments on drying kinetics of thompson seedless grapes". Journal of Food Engineering, 39, 211-216, 1999.

[30] Doymaz I. "Experimental study on drying of pear slices in a convective dryer". International Journal of Food Science and Technology, 48, 1909-1915, 2013.

[31] Dissa AO, Desmorieux H, Savadogo PW, Segda BG, Koulidiati J. "Shirinkage porosity abd density behaviour during convective drying of spirlulina". Journal of Food Engineering, 97(3), 410-418, 2010.

[32] Moffat RJ. "Describing the uncertainties in experimental results". Experimental Thermal and Fluid Science, 1(1), 3-17, 1988.

[33] Akpınar EK. "Deneysel çalışmalardaki hata analizine bir örnek: Kurutma deneylerindeki hata analizi”, Mühendis ve Makine, 46(540), 41-48, 2005.

[34] Bart-Plange A, Addo A, Ofori H, Asare V. "Thermal properties of gros michel banana grown in Ghana". ARPN Journal of Engineering and Applied Sciences, 7(4), 478-484, 2012.

[35] Mercali GD, Tessaro IC, Norena CPZ, Marczak LDF. "Mass transfer kinetics during osmotic dehydration of bananas (Musa sapientum, shum.)". International Journal of Food Science and Technology, 45(11), 2281-2289, 2010.

[36] Afolabi TJ, Agarry SE. "Mathematical modelling and simulation of the mass and heat transfer of batch convective air drying of tropical fruits". Chemical and Process Engineering Research, 23, 9-19, 2014.

[37] Izli N, Isik E. "Color and microstructure properties of tomatoes dried by microwave, convective, and microwave-convective methods". International Journal of Food Properties, 18, 241-249, 2015.

[38] Seyedabadi E, Khojastehpour M, Abbaspour-Fard MH. "Convective drying simulation of banana slabs considering non-isotropic shrinkage using FEM with the Arbitrary Lagrangian-Eulerian method". International Journal of Food Properties, 20, 36-49, 2017.

[39] Comsol Multiphysics 5.3. "Heat Transfer Model Library". Heat Transfer Module User's Guide, USA, 2017.

[40] Izli N, Isik E. "Effect of Different Drying Methods on Drying Characteristics, Colour and Microstructure Properties of Barbunia Bean (Phaseolus vulgaris L.)". Journal of Agricultural Faculty of Gaziosmanpasa University, 33(2), 79-88, 2016.

[41] Pagliarini E, Vernile M, Peri C. "Kinetics study on color changes in milk due to heat". Journal of Food Science, 55(6), 1766-1767, 1990.

[42] Zogzas NP, Maroulis ZB, Marinos-Kouris D. "Moisture diffusivity data compilation in foodstuffs". Drying Technology, 14, 2225-2253, 1996. 
[43] Liu G, Chen J, Liu M, Wan X. "International Conference on Advances in Computational Modeling and Simulation Shrinkage, porosity and density behaviour during convective drying of bio-porous material". Procedia Engineering, 31, 634-640, 2012. 